\title{
Serum concentrations of soluble 4-1BB and 4-1BB ligand correlated with the disease severity in rheumatoid arthritis
}

\author{
Hyo Won Jung ${ }^{1}$, Seung Won Choi ${ }^{2}$ \\ Jung IL Choi ${ }^{1}$ and Byoung Se Kwon ${ }^{1,3,4}$ \\ ${ }^{1}$ The Immunomodulation Research Center \\ Department of Biological Sciences \\ University of Ulsan \\ Ulsan 680-749, Korea \\ ${ }^{2}$ Division of Allergy and Rheumatology \\ Department of Internal Medicine \\ Ulsan University Hospital \\ Ulsan 682-714, Korea \\ ${ }^{3}$ LSU Eye Center, 2020 Gravier Street \\ New Orleans LA 70112 \\ ${ }^{4}$ Corresponding author: Tel, 82-52-259-2392; \\ Fax, 82-52-259-2740; E-mail, bskwon@mail.ulsan.ac.kr
}

Accepted 1 December 2003

Abbreviations: $B D$, Behcet's disease; RA, rheumatoid arthritis; s4-1BB, soluble 4-1BB; s4-1BBL, soluble 4-1BB ligand; SLE, systemic lupus erythematosus

\begin{abstract}
Rheumatoid arthritis (RA) is a multifactorial autoimmune disease whose etiopathogenesis is not well understood. Although soluble (s) forms of 4-1BB (s4-1BB) and 4-1BB legand (s4-1BBL) have been detected in the sera of RA patients, their significance is not known. We compared the serum levels of s4-1BB and s4-1BBL in RA patients with those in systemic lupus erythematosus (SLE) and Behcet's disease (BD) patients. Serum levels of s4-1BB and s4-1BBL were significantly higher in RA patients compared with healthy controls, SLE or BD patients, and the abundance was correlated with disease severity in patients with $R A$. The serum levels of s4-1BB in RA patients were inversely corroborated with 4-1BB expression levels on activated $T$ lymphocytes. In addition, there was a correlation between serum levels of s4-1BB and $s 4-1 B B L$. The augmented secretion of $s 4-1 B B$ and s4-1BBL levels into the serum may reflect the clinical symptoms of RA and levels of s4-1BB and s4-1BBL in sera at the time of diagnosis may be indicative of the severity and outcome of RA.
\end{abstract}

Keywords: autoimmune diseases; Behcet syndrome; biological markers; lupus erythematosus systemic; rheumatoid arthritis; serum

\section{Introduction}

Rheumatoid arthritis (RA) is a chronic inflammatory disease characterized by radiographic joint destruction, severe functional deterioration, and work disability (American College of Rheumatology Ad Hoc Committee on Clinical Guidelines, 1996). It is thought to involve autoimmune recognition of self-antigens by autoreactive $T$ lymphocytes. The cause of this breakdown of tolerance to self-antigens is not known, but probably involves impairment of apoptosis of potentially pathogenic and autoreactive $T$ lymphocytes (Pender, 1998). As a consequence, the elimination of autoreactive cells and down-regulation of lymphocyte responses are defective.

4-1BB (CD137), a member of the tumor necrosis factor (TNF) receptor family, is expressed on activated T lymphocytes (Kwon and Weissman, 1989; Schwarz et al., 1995). It generates either co-stimulatory signals leading to $T$ cell activation and proliferation, or death signals (Alderson et al., 1994), and may promote tumor rejection in vivo (May et al., 2002). A recent report suggests that cross-linking of the membrane-bound 4-1BB induces apoptosis of activated $T$ lymphocytes by a Fas-independent pathway (Michel et al., 1999).

4-1BB ligand (4-1BBL) is expressed on activated $A P C s$, including IFN-g-activated macrophages, Ig or CD40 ligand-activated B cells (Pollok et al., 1994), primary B cells and B-cell lines (Zhou et al., 1995) or monocytes, splenic dendritic cells (Futagawa et al., 2002). There are reports, indicating that $4-1 \mathrm{BBL}$ can argument $\mathrm{T}$ cell proliferation, cytokine production and cytolytic effector function and prevent activation- induced cell death (DeBenedette et al., 1997; Gramaglia et al., 2000).

Soluble forms of receptors among the members of the TNF receptor family have been discovered. These include CD27, CD30 and CD95 (Nozawa et al., 1997; Metkar et al., 2000; Lienhardt et al., 2002). These soluble receptor forms are generated by proteolytic cleavage (Matsuno et al., 2000) or alternative splicing (Inaba et al., 1999), leading to the inhibition of biological activities of TNF. A soluble form of $4-1 B B$ (s4-1BB), released by activated lymphocytes has 
been shown to involve in negative feedback control of inflammation in autoimmune disease like rheumatoid arthritis (Setareh et al., 1995). The level of s4$1 \mathrm{BB}$ is inversely correlated with lymphocytes proliferation, and positively reflects the degree of activationinduced cell death caused by mitogen stimulation (Michel and Schwarz, 2000). High levels of s4-1BB have been detected in sera of patients with rheumatoid arthritis (Michel et al., 1998) and multiple sclerosis (Sharief, 2002) probably reflecting prolonged abnormal immune responses. The precise role of s4$1 \mathrm{BB}$ or $\mathrm{s} 4-1 \mathrm{BBL}$ in autoimmune diseases is, however, not completely understood.

In this study, we investigate the levels of surface expressions of $4-1 B B$ and $4-1 B B L$ on the surface of PBMC of both normal healthy donors and RA patients. Additionally correlations were drawn between the kinetics and abundance of serum content of s4-1BB and s4-1BBL and serological parameters of RA.

\section{Materials and Methods}

\section{Patients}

RA patients were randomly selected from the patients treated in the Department of Allergy and Rheumatology, Ulsan University Hospital, Ulsan, Korea. The RA patients selected for the present investigation were classified as clinically active according to the American College of Rheumatology criteria revised in 1987 (Arnett et al., 1988). A total of thirty randomly selected patients (twenty-five females and five males) ranged in age from 34 to 70 years with a mean age of $48 \pm 11$ (mean $\pm S D$ ) years with rheumatoid factorpositive. Peripheral blood samples were obtained from the patients with RA before the start of immunosuppressive therapy. The samples were also obtained from healthy donors presenting with non-specific disorders, to serve as normal controls. Disease severity was evaluated using RA diagnosis serological parameters such as rheumatoid factor (RF), erythrosedimentation rate (ESR), C reactive protein (CRP), and white blood cell count (WBC). Six patients of RA who responded to the immunosuppressive therapy, were particularly analyzed over several months.

\section{Surface expression of 4-1BB and 4-1BBL}

In order to study the surface expression of $4-1 B B$ and $4-1 B B L$ on PBMC, the frequency of $4-1 B B$ or $4-1 B B L$ positive cells as well as the intensity of $4-1 B B$ and 4-1BBL expression were analyzed by flow cytometry in twenty patients with RA and compared with healthy controls.

PBMC were prepared by Ficoll gradient density centrifugation, and $2 \times 10^{6}$ cells were stimulated with or without $1 \mathrm{mg} / \mathrm{ml}$ anti-human CD3 (OKT3) monoclonal antibody (mAb) or $5 \mathrm{mg} / \mathrm{ml}$ PHA for $24 \mathrm{~h}$. They were washed and resuspended in $500 \mathrm{ml}$ FACS buffer (1×PBS, 2\% BSA, $0.1 \% \quad \mathrm{NaN}_{3}$ ) and stained for 30 min at $4{ }^{\circ} \mathrm{C}$ with appropriate concentrations of fluorochrome-labeled monoclonal antibodies; markers for T cells (CD4 and CD8), B cells (CD19), monocytes (CD14) were used. After two washes with FACS buffer, cells were analyzed by flow cytometry using FACScan and Lysis II software (Becton Dickinson, Mountain View, CA). Samples were analyzed by setting appropriate SSC/FSC gates around the lymphocyte populations. All antibodies were purchased from BD Biosciences (PharMingen, San Diego, CA).

\section{Detection of s4-1BB and s4-1BBL in serum}

Serum levels of $\mathrm{S4}-1 \mathrm{BB}$ and $\mathrm{s} 4-1 \mathrm{BBL}$ were measured by an enzyme-linked immunosorbent assay (ELISA). Serum samples were frozen immediately following collection and thawed just before assay (Kim et al., 2002). All assays were performed in a blind fashion. ELISA microtiter plates were coated overnight at $4^{\circ} \mathrm{C}$ with $1 \mathrm{mg} / \mathrm{ml}$ of anti-4-1BB mAb (AB 4815, Immunomics, Co. Ulsan, Korea) or $1 \mathrm{mg} / \mathrm{ml}$ of anti-4-1BBL $\mathrm{mAb}$ (AB 5G11; Immunomics). Purified human recombinant 4-1BB-Fc or 4-1BBL-Fc (PeproTech, Inc. Rocky Hill, NJ) were used as standards. Non-specific binding was blocked by addition of $100 \mathrm{ml} /$ well of $4 \%$ $B S A$ in phosphate buffered saline (PBS) for $2 \mathrm{~h}$ at $37^{\circ} \mathrm{C}$; the samples were then diluted, and added to the wells in duplicate. The microtiter plates were washed and incubated with $100 \mathrm{ml} /$ well of detecting anti-4-1BB mAb (AB 4785-biotin, Immunomics) or anti-4-1BBL mAb (AB 4H3-biotin, Immunomics) in 1\% BSA-PBS for $2 \mathrm{~h}$ at $37^{\circ} \mathrm{C}$, then washed before the addition of $100 \mathrm{ml} /$ well of a $1 / 5,000$ solution of HRP. straptavidin in $1 \%$ BSA-PBS. They were incubated further for $1 \mathrm{~h}$ at $37^{\circ} \mathrm{C}$, washed, and developed using the TMB peroxidase substrate system (Endogen, BD Bioscience). Absorbance was measured at $450 \mathrm{~nm}$.

For comparison, serum $\mathrm{s} 4-1 \mathrm{BB}$ and $\mathrm{s} 4-1 \mathrm{BBL}$ were determined in the patients with systemic lupus erythematosus (SLE), a prototypic autoimmune disease and Behcet's disease (BD), a chronic relapsing multisystem inflammatory disorder.

\section{Serological parameters}

Total serum lactate rheumatoid factor $(R F ; I U / m L), C$ reactive protein (CRP; $\mathrm{mg} / \mathrm{dL})$, and erythrosedimentation rate $(E S R ; \mathrm{mm} / \mathrm{h})$ were determined by standard methods (Noel et al., 1992). White blood cell counts (WBC; cells $/ \mathrm{ml}$ ) were made with a haematology analyzer. 


\section{Statistical analysis}

Student's $t$ test was used to analyze 4-1BB and 4-1BBL data, which are expressed as means $\pm S D$. Correlation between $\mathrm{s4-1BB}$ or $\mathrm{s4-1BBL}$ levels within patient groups and in normal controls was assessed by one-way ANOVA performed with the Microcal ${ }^{\mathrm{TM}}$ Orijin $^{T M}$ software package (MicrocalSoftware, Inc, Northampton). $P$-values of less than 0.05 are considered statistically significant.

\section{Results}

\section{Surface expression of 4-1BB and 4-1BBL on PBMC}

$P B M C$ isolated from twenty patients at the disease onset of RA were cultured for $24 \mathrm{~h}$ in 24-well plates in $1 \mathrm{ml} \mathrm{RPMI-1640}$ with or without OKT3 or PHA stimulation and the levels of surface expression of 4-1BB and 4-1BBL were determined by FACS. OKT3 stimulation induces $4-1 \mathrm{BB}$ on $\mathrm{T}$ cells and PHA stimulation provokes $4-1 \mathrm{BBL}$ on $\mathrm{B}$ cells and monocytes. Isotype-matched and unrelated $m A b s$ were used for each fluorescence parameter to correct for nonspecific binding of each indicated $m A b$.

Surface expression of $4-1 B B$ on PBMC from RA patients was much less than that on PBMC from healthy donors (Figure 1). Approximately $5.59 \%$ of PBMC (mean $\pm S D ; 5.59 \pm 3.81 \%$ ) from RA patients expressed low levels of 4-1BB compared with $16.6 \%$ in healthy donors $(16.6 \pm 8.16 \%)$ upon OKT3 stimu- lation. The surface expression levels of $4-1 \mathrm{BB}$ on activated PBMC ranged between 0.05 and $11.5 \%$ in RA patients, and between 3.06 and $32.47 \%$ in healthy donors, respectively. The expression level of $4-1 \mathrm{BB}$ was significantly lower $(P<0.0001)$ on PBMC of RA patients than that of healthy controls in OKT3 stimulation. 4-1BB was not detected on resting PBMC of both healthy donors and RA patients.

On the other hand, PBMC from RA patients expressed high levels of $4-1 \mathrm{BBL}(18.19 \pm 10.63 \%)$ after OKT3 stimulation compared with those of healthy donors $(9.9 \pm 8.22 \%)$ (Figure 1). Surface expression levels of $4-1 \mathrm{BBL}$ on activating PBMC ranged between 5.86 and $42.59 \%$ in RA patients, and between 4.09 and $22.73 \%$ in healthy donors, respectively. The expression level of $4-1 \mathrm{BBL}$ on activating PBMC was significantly high on that of patients with RA $(P<$ $0.05)$ compared with the healthy donors. Particularly, 4-1BBL expression was significantly high levels $(P<$ $0.001)$ on resting PBMC $(9.9 \pm 8.22 \%)$ with RA patients compared with healthy control group (2.54 \pm $1.75 \%)$.

Thus, 4-1BB expression was observed on both $\mathrm{CD} 4^{+}$ and $C D 8^{+} T$ cells from RA patients after activation but not present on resting $T$ cells from RA patients (Figure $2 \mathrm{~A}$ ) or those from healthy donors (Figure 2B). On the other hand, 4-1BBL was constitutively expressed on antigen presenting cells (APCs) such as $C D 19^{+} B$ cells and $\mathrm{CD} 14^{+}$monocytes from RA patients but not on $\mathrm{T}$ cells further induced after activation (Figure 2A) compared with healthy donors (Figure 2B).

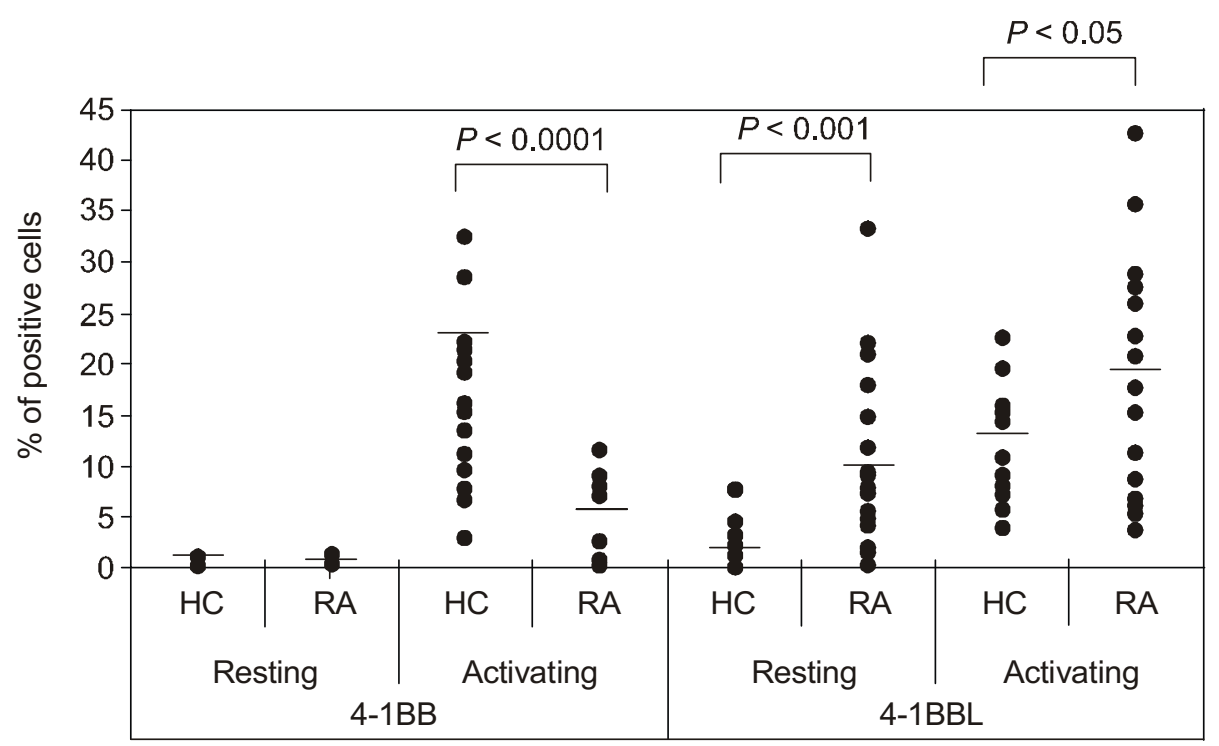

Figure 1. Surface expression levels of $4-1 \mathrm{BB}$ and $4-1 \mathrm{BBL}$ on PBMC from the patients with rheumatoid arthritis (A) and healthy donors (B). PBMC from twenty RA patients and healthy donors were prepared by Ficoll gradient density centrifugation and $2 \times 10^{6}$ cells were cultured in the absence (resting) or presence (activating) of $1 \mathrm{mg} / \mathrm{ml} \mathrm{OKT3} \mathrm{or} 5 \mathrm{mg} / \mathrm{ml}$ of PHA. The surface expression of 4-1BB and 4-1BBL was determined by flow cytometry after $24 \mathrm{~h}$. PE-conjugated anti-4-1BB and anti-4-1BBL mAbs (BD PharMingen) were used to detect PBMC that expressed $4-1 \mathrm{BB}$ and $4-1 \mathrm{BBL}$. Horizontal bars depict means $(n=20)$. RA, rheumatoid arthritis and $\mathrm{HC}$, healthy control group. 
A

CD4
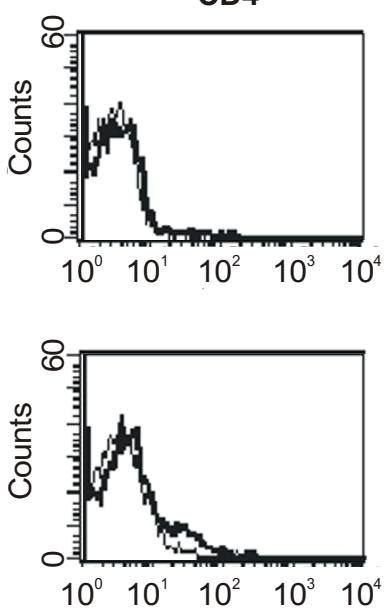

CD8
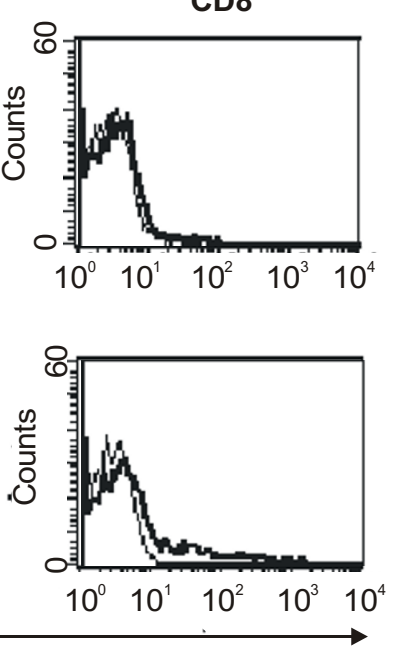

4-1BB
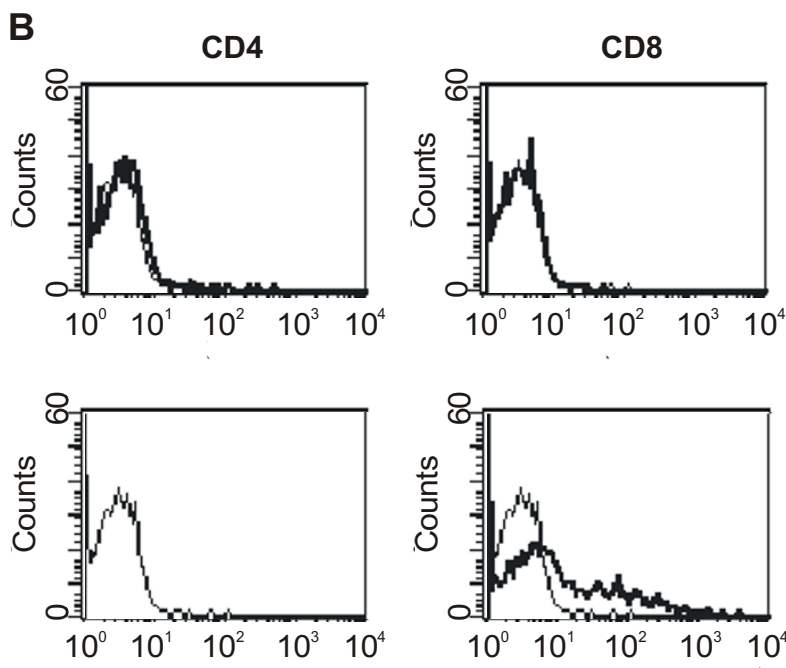

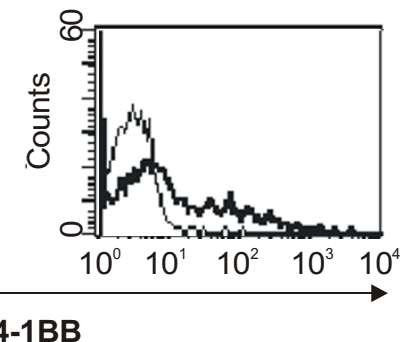

CD14
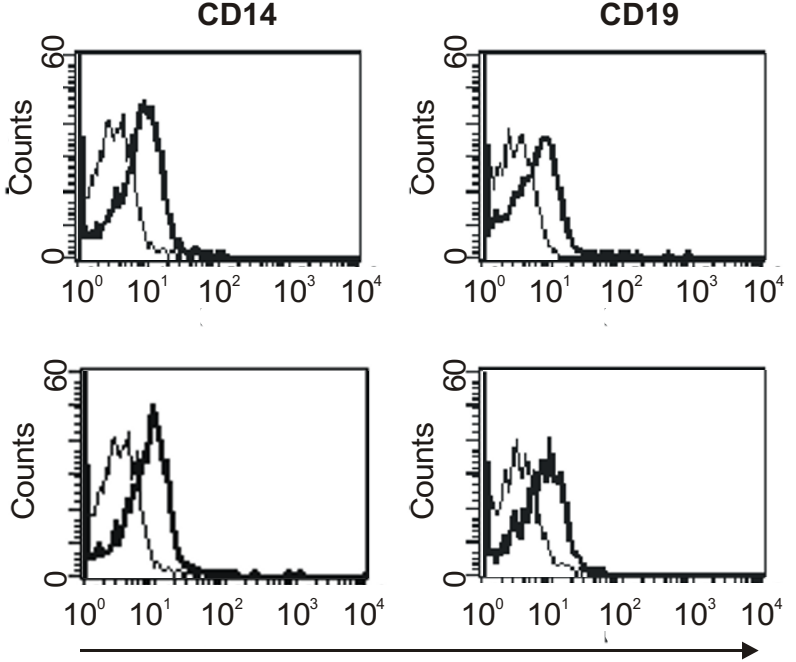

4-1BBL
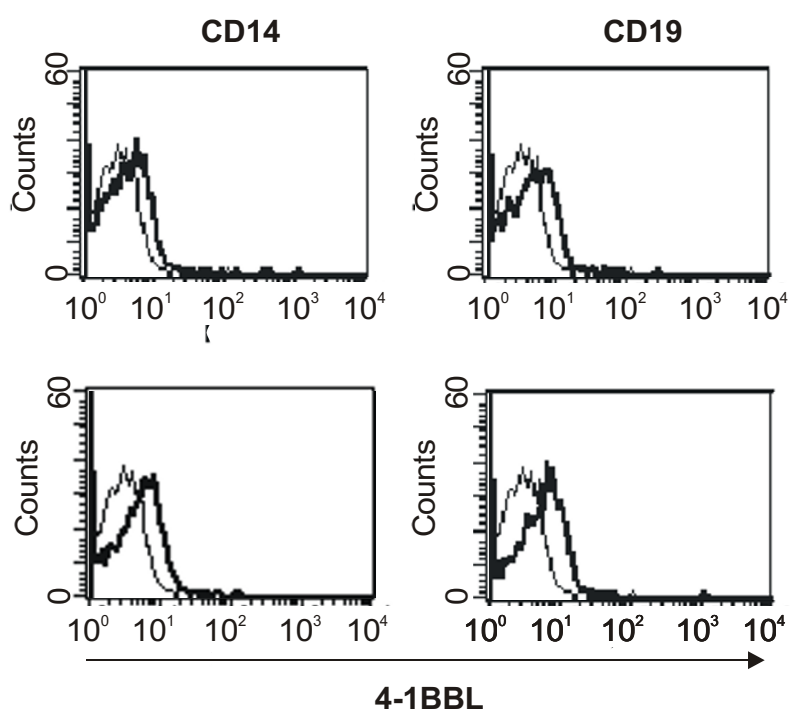

Figure 2. Surface expression of $4-1 \mathrm{BB}$ and $4-1 \mathrm{BBL}$ on $\mathrm{PBMC}$ from the patients with rheumatoid arthritis $(\mathrm{A})$ and healthy donors $(B)$. $P B M C$ cultured in absence (upper panel) or presence (lower panel) of OKT3 or PHA as mentioned in Materials and Methods. PE-conjugated anti-4-1BB, 4-1BBL mAbs and FITC-conjugated anti-CD4, CD8, CD19, and CD14 mAbs (BD PharMingen) were used to detect 4-1BB and 4-1BBL expression (thick lines). Isotype-matched antibodies were used as controls (thin lines). Analysis was performed on a FACscan and analyzed using Lysis II software.

\section{Serum levels of $s 4-1 B B$ and s4-1BBL}

s4-1BB and s4-1BBL were determined by ELISA with the serum samples collected from healthy donors or RA patients and other disorders such as SLE and BD.

The sera of the healthy control group contained low levels of s4-1BB (mean $\pm S D ; 272 \pm 225 \mathrm{pg} / \mathrm{ml}$ ) (Figure 3 ). The levels of $\mathrm{s} 4-1 \mathrm{BB}$ ranged between 27 and $681 \mathrm{pg} / \mathrm{ml}$, with a median of $200 \mathrm{pg} / \mathrm{ml}$. Substantially higher serum levels of $s 4-1 B B$ were detected in patients with RA, SLE, and BD compared to healthy donors. The highest $s 4-1 B B$ levels were detected in patients with RA $(2,964 \pm 3,840 \mathrm{pg} / \mathrm{ml})$ : the range was between 172 and $16,069 \mathrm{pg} / \mathrm{ml}$, with a median of $957 \mathrm{pg} / \mathrm{ml}$. Values $(961 \pm 577 \mathrm{pg} / \mathrm{ml})$ in SLE patients were between 190 and $1,802 \mathrm{pg} / \mathrm{ml}$, with a median of $684 \mathrm{pg} / \mathrm{ml}$. In BD patients, s4-1BB levels $(1,128 \pm 585 \mathrm{pg} / \mathrm{ml})$ were between 474 and 1,996 $\mathrm{pg} / \mathrm{ml}$, with a median of $864 \mathrm{pg} / \mathrm{ml}$. The level of s4-1BB was significantly elevated in the sera of patients with RA $(P<0.0001)$, with SLE $(P<0.001)$, and with $\mathrm{BD}(P<0.001)$ compared with healthy donors.

The sera of the healthy control group contained 


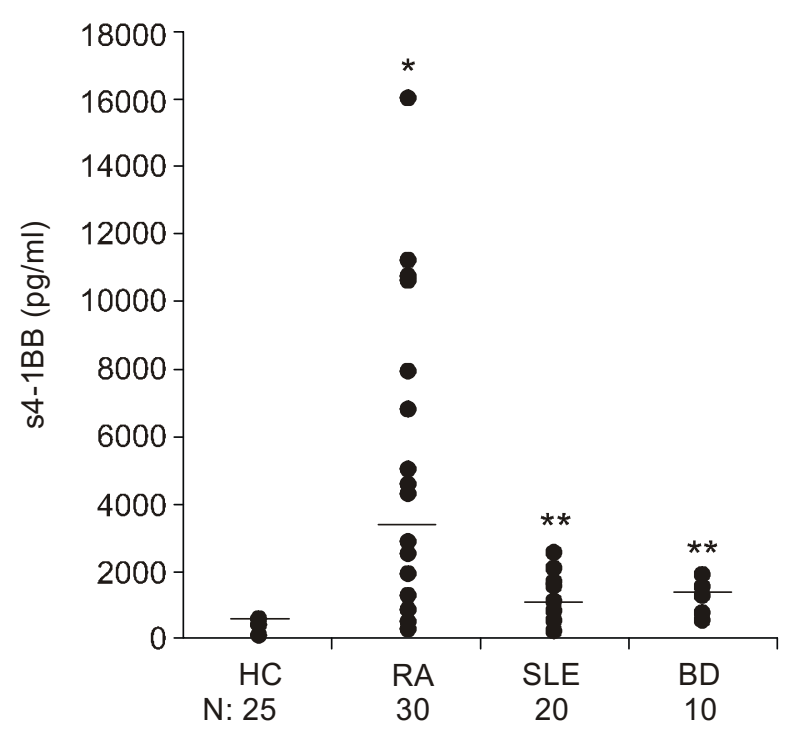

Figure 3. Comparison of the $s 4-1 B B$ levels in sera of patients with rheumatoid arthritis with those of other autoimmune diseases and healthy control. Serum samples were investigated by ELISA. ${ }^{*} P<$ 0.0001 and ${ }^{* *} P<0.001$ compared with serum levels in healthy controls. Horizontal bars depict means. The data shown are means of triplicates. RA, active rheumatoid arthritis; SLE, systemic lupus erythematosus; $B D$, Behcet's disease; and $H C$, healthy control. $n$. numbers of donors in each group.

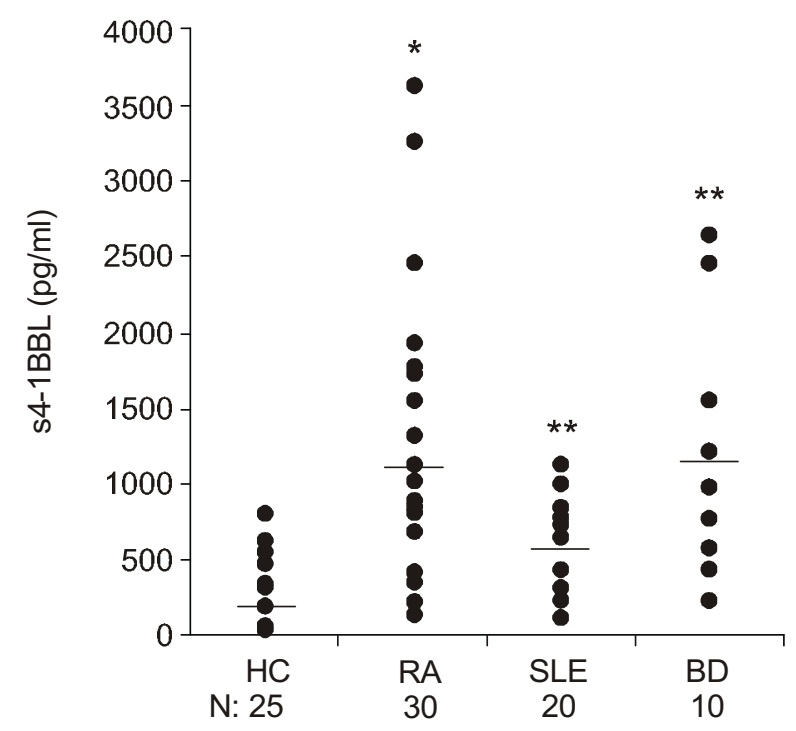

Figure 4. The s4-1BBL profiles in sera of patients with rheumatoid arthritis, other autoimmune diseases and healthy control. Serum samples were investigated by ELISA. ${ }^{*} P<0.0001$ and ${ }^{* *} P<0.001$ compared with serum levels in healthy control. Horizontal bars depict means. The data shown are means of triplicates. RA, active rheumatoid arthritis; SLE, systemic lupus erythematosus; BD, Behcet's disease; and $\mathrm{HC}$, healthy control. n. numbers of donors in each group

low levels of s4-1BBL (mean $\pm S D ; 197 \pm 225 \mathrm{pg} / \mathrm{ml}$ ) (Figure 4) ranging between 36 and $804 \mathrm{pg} / \mathrm{ml}$, with a median of $108 \mathrm{pg} / \mathrm{ml}$. Significantly higher levels
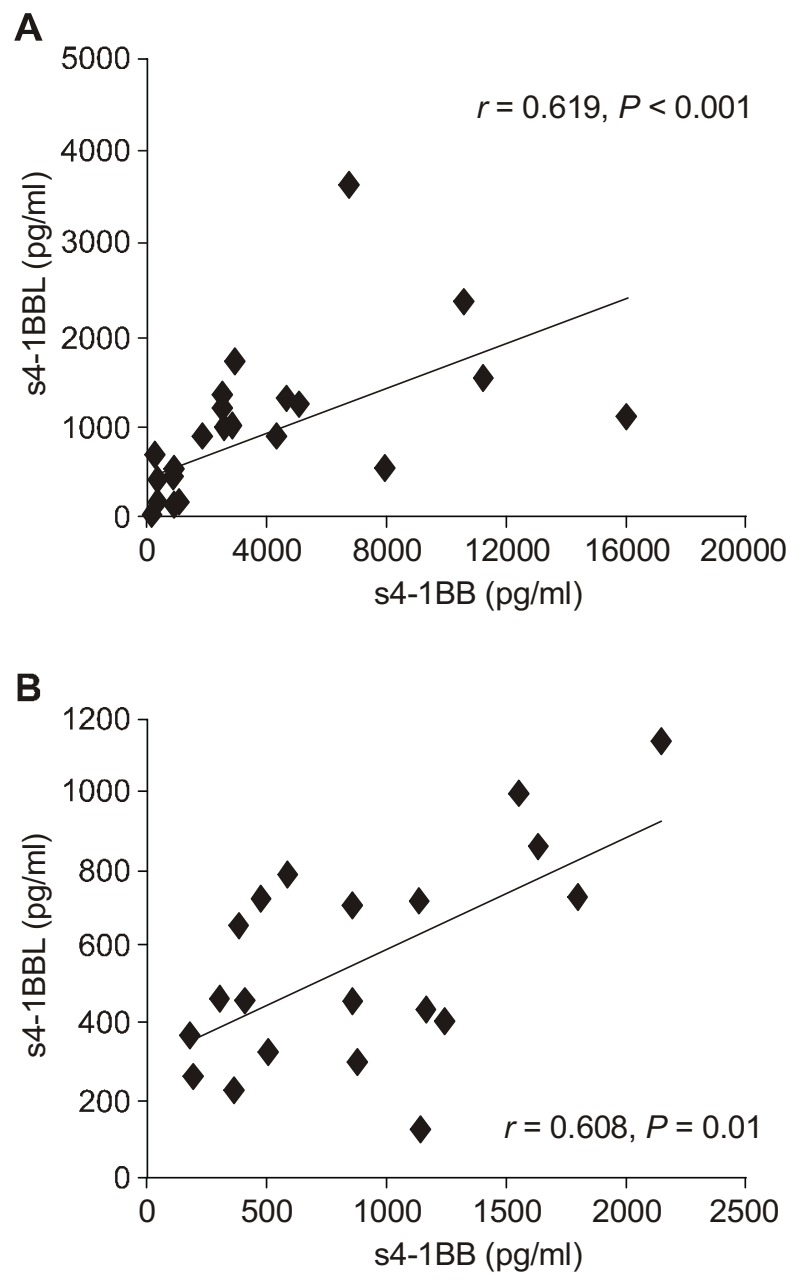

Figure 5. Correlation between $s 4-1 \mathrm{BB}$ and $s 4-1 \mathrm{BBL}$ in sera of the patients with rheumatoid arthritis (A) and systemic lupus erythematosus (B). s4-1BB and s4-1BBL were assessed by ELISA.

were detected in patients with active RA, SLE, and BD. Greatest levels of $s 4-1 B B L$ were also detected in sera from patients with RA $(1,034 \pm 916 \mathrm{pg} / \mathrm{ml})$ ranging was between 130 and $3,636 \mathrm{pg} / \mathrm{ml}$, with a median of $882 \mathrm{pg} / \mathrm{ml}$. In SLE patients $(598 \pm 247$ $\mathrm{pg} / \mathrm{ml}$ ), s4-1BBL levels were between 121 and 1135 $\mathrm{pg} / \mathrm{ml}$, with a median of $549 \mathrm{pg} / \mathrm{ml}$. In BD patients $(1,207 \pm 861 \mathrm{pg} / \mathrm{ml})$, they were between 228 and 2,652 $\mathrm{pg} / \mathrm{ml}$, with a median of $1,204 \mathrm{pg} / \mathrm{ml}$. The level of s4-1BBL was significantly elevated in sera with patients of RA $(P<0.0001)$, of SLE $(P<0.001)$, and of BD $(P<0.001)$ compared with healthy donors.

The data clearly indicates that levels of s4-1BB and s4-1BBL are greatly increased in sera of patients with autoimmune disorders such as RA, SLE and BD. Serum s4-1BB levels in RA $(r=0.619, P<0.001)$ (Figure 5A) and SLE $(r=0.608, P<0.01)$ (Figure $5 B)$ were strongly correlated with raised serum s4$1 \mathrm{BBL}$ values. 

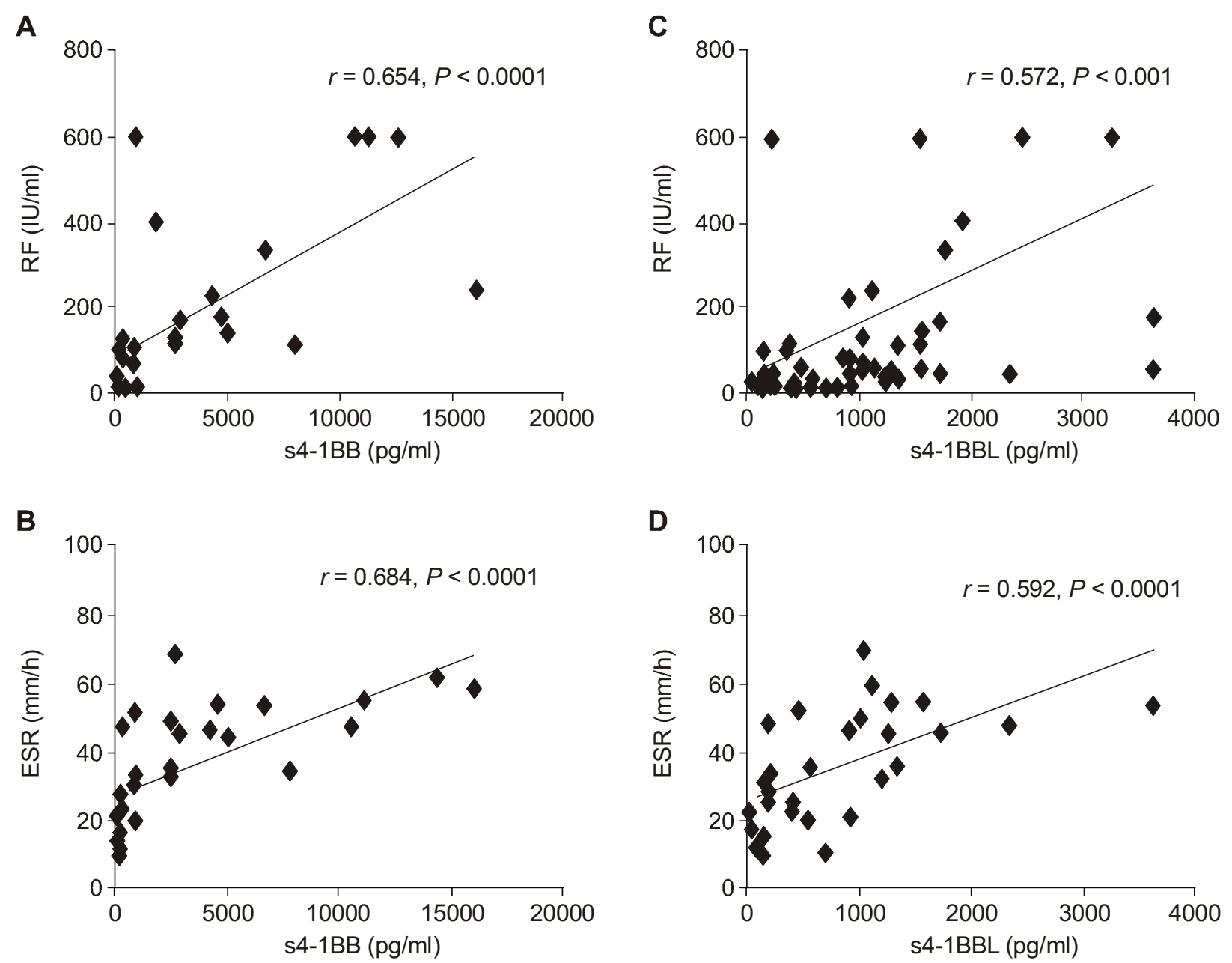

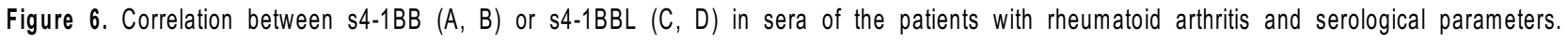
$\mathrm{RF}$; rheumatoid factor $(\mathrm{IU} / \mathrm{ml})$ and $\mathrm{ESR}$; erythrocyte sedimentation rate $(\mathrm{mm} / \mathrm{h})$.

\section{Correlation between s4-1BB or 4-1BBL and serological RA parameters}

We sought to evaluate the relationship between release of s4-1BB and serological parameters of RA such as RF, CRP, WBC and ESR. In the RA patient group, s4-1BB levels were correlated with RF values $(r=0.654 ; P<0.0001$, Figure $6 \mathrm{~A})$ and $\mathrm{ESR}$ values $(r=0.684 ; P<0.0001$, Figure $6 \mathrm{~B})$. The correlation between serum levels of $s 4-1 B B L$ and RF or ESR in patients with active RA also reached statistically significant levels, $(r=0.572 ; P<0.001$ for RF, Figure $6 C)$ and $(r=0.592 ; P<0.001$ for ESR, Figure 6D). Additional two serological parameters, CRP and WBC, were not significantly correlation with $\mathrm{S4}-1 \mathrm{BB}$ and s4-1BBL in the RA patient group (data not shown).

\section{The effect of therapy in active $R A$}

Serum s4-1BB and s4-1BBL levels in patients with RA were compared at disease onset and upon treatment with immunosuppressive therapy in Figure 7. Six patients with active RA had levels of $\mathrm{s} 4-1 \mathrm{BB}$ ranging between 2,784 and 16,069 $\mathrm{pg} / \mathrm{ml}$ (mean $\pm S D ; 6,958$ $\pm 5,343$ ) while for $s 4-1 \mathrm{BBL}$ the range was between 1,032 and $2,339 \mathrm{pg} / \mathrm{ml}(1,392 \pm 477)$. However, at the quiescent stage following immunosuppressive therapy, the levels have markedly decreased; for s4-1BB (Figure $7 \mathrm{~A}$ ) the range was between 388 and 957 $\mathrm{pg} / \mathrm{ml}(672 \pm 252)$ and for s4-1BBL (Figure 7B), it was between 96 and $540 \mathrm{pg} / \mathrm{ml}(322 \pm 191)$, with $P<0.05$ and $P<0.01$, respectively, compared with patients at disease onset. All patients with RA over the duration of study showed improvement and levels of CRP, $E S R$, and WBC decreased upon immunosuppressive therapy (Table 1). 

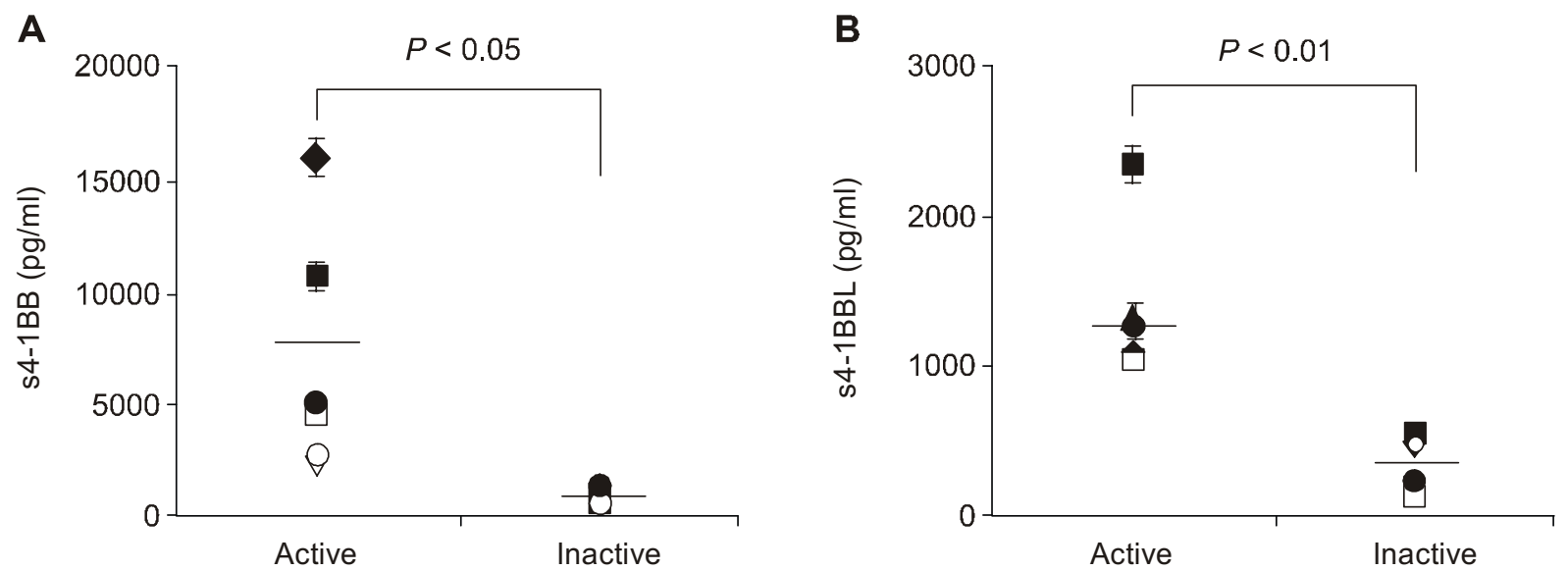

Figure 7. $s 4-1 B B(A)$ and $s 4-1 B B L(B)$ levels in sera of six patients with $R A$ in active and inactive stage. $s 4-1 B B$ and $s 4-1 B B L$ were assessed by ELISA. $P<0.01$ and $P<0.05$ respectively for the comparison of serum levels of s4-1BB and s4-1BBL between active and inactive stage. Donor number $1(\square)$; donor $2(\mathbf{\square})$; donor $3(\mathbf{\Delta})$; donor $4(\circ)$; donor $5(\bullet)$; and donor $6(\diamond)$.

Table 1. The levels of serological parameters of the patients with rheumatoid arthritis in active and inactive stage

\begin{tabular}{cccccccc} 
Patient & Age/sex & \multicolumn{3}{c}{ Active stage } & & \multicolumn{2}{c}{ Inactive stage following treatment } \\
& & CRP & ESR & WBC & CRP & ESR & WBC \\
\hline 1. & $70 / \mathrm{M}$ & 0.4 & 55 & 15900 & 0.03 & 28 & 4700 \\
2. & $42 / \mathrm{F}$ & 0.32 & 48 & 4230 & 0.05 & 25 & 4800 \\
3. & $37 / \mathrm{F}$ & 1.22 & 33 & 7170 & 0.19 & 12 & 4790 \\
4. & $46 / \mathrm{F}$ & 14.22 & 54 & 7930 & 0.09 & 23 & 8570 \\
5. & $49 / \mathrm{F}$ & 0.18 & 46 & 8160 & 0.08 & 1 & 15480 \\
6. & $53 / \mathrm{F}$ & 1.81 & 59 & 6090 & 0.03 & 10 & 6730
\end{tabular}

CRP, C reactive protein $(\mathrm{mg} / \mathrm{dL})$; ESR, erythrocyte sedimentation rate $(\mathrm{mm} / \mathrm{hour}$ ); WBC, white blood cell counts (cells/ul); $\mathrm{F}$, female; $\mathrm{M}$, male.

\section{Discussion}

4-1BB has been found on activated $T$ cells and NK cells (Melero et al., 1998). 4-1BBL on several kinds of APCs (Pollok et al., 1994; Zhou et al., 1995; Futagawa et al., 2002) such as activated B cells, monocytes, activated macrophages, splenic dendritic cells; it can also be induced on $\mathrm{T}$ lymphocytes. A two-way transduction of signals seems to operate in the 4-1BB receptor-ligand system. Cross-linking of 4$1 \mathrm{BB}$ activates T-cells leading to cytokine release. On the other hand, cross-linking of its ligand by 4-1BB induces apoptosis of activated T lymphocytes (Michel et al., 1999). Reverse signaling following cross-linking of $4-1 \mathrm{BBL}$ in lymphocytes inhibits proliferation and induces apoptosis (Langstein et al., 1998; Ebta et al., 2001). In addition, 4-1BB also causes apoptosis of B-cells by direct cell contact (Kienzle and Kempis, 2000).

4-1BB is normally expressed when $T$ cells receive signals through TCR. Therefore, anti-CD3 mAb (OKT3) is one of the better 4-1BB inducer in $T$ cells. 4-1BBL can be induced by stimulating $B$ cells, monocytes and dendritic cells by PHA. We hypothesized that both 4-1BB and 4-1BBL were expressed on higher percentage of PBMC in RA patients. Therefore we compared their expression patterns between healthy control and RA patients before and after respective stimuli. Although 4-1BBL showed higher expression before and after PHA stimulus as expected, 4-1BB on $T$ cells was unexpectedly resistant to induction in RA patients. This may indicate that higher percentage of $T$ cells is in anergic state in RA patients.

The level of 4-1BB was lower on activating PBMC from RA patients than that of healthy controls (Figure 1). In contrast constitutive expression of 4-1BBL on PBMC from RA patients was higher than that on PBMC from healthy donors. Since reverse signaling through 4-1BBL in $\mathrm{T}$ cells induces apoptosis (Langstein et al., 1998), the high expression of 4-1BBL therefore 
is likely to play an important role in disease progress and regulating the outcome of cell interactions in autoimmune disease such as RA. 4-1BB was expressed on both activated $\mathrm{CD} 4^{+}$and $\mathrm{CD} 8^{+} \mathrm{T}$-cell subpopulations by OKT3 stimulation (Figure 2). On the other hand, 4-1BBL was expressed on small populations of $\mathrm{CD} 19^{+} \mathrm{B}$-cells and $\mathrm{CD} 14^{+}$monocytes.

In RA, large number of memory $T$ cells was detected in the synovium (Toshihiro et al., 2000; Maldonado et al., 2003). Such enhanced migration of the memory cells to sites of inflammation may play a role in the pathogenesis of RA (Maldonado et al., 2003). 4-1BB was expressed upon activation in the memory $T$ cell populations in humans (Garni-Wagner et al., 1996). In the future studies, 4-1BB expression in the nave and the memory $T$ cells from both synovial fluid and peripheral blood will be determined in different phases of RA. These studies may provide a clue to the role of $4-1 \mathrm{BB}$ and $4-1 \mathrm{BBL}$ in the pathogenesis of RA.

Several receptor and their ligands belonging to the TNF family are released in soluble form following cleavage from the cell surface (Metkar et al., 2000). These may affect cell-cell interactions and responses to receptor-ligand interactions or provoke more distal responses to cellular activation. In the case of soluble Fas (sFas), the presence of an excess of sFas may interfere with the trimerization of the Fas/CD95 receptor by its ligand leading to apoptosis (Schneider et al., 1988; Seo et al., 2002). s4-1BB is released by activated lymphocytes and is generated by proteolytic cleavage (Michel and Schwarz, 2000). s4-1BBL is also released constitutively from leukocytes by differential splicing of the membrane-bound molecule and more is released following activation, and this is prevented by the addition of a metalloproteinase inhibitor (Hulmut et al., 2001). We analyzed s4-1BB (Figure 3) and s4-1BBL (Figure 4) levels in serum samples from patients with RA and other disorders as well as healthy donors and found that, while only very low levels of $s 4-1 B B$ and $s 4-1 B B L$ were present in sera from healthy control group, elevated levels were detectable in the sera of patient group. RA was particularly severe in releasing $\mathrm{s} 4-1 \mathrm{BB}$ and $\mathrm{s} 4-1 \mathrm{BBL}$. We found that both $s 4-1 B B$ and $s 4-1 B B L$ were detected at high level in sera of patients of another autoimmune disease, SLE and an inflammatory disorder of unknown etiology, BD. The significance of these findings is currently unknown. This finding confirms and extends results from earlier studies demonstrating that patients with rheumatic disease (Michel et al., 1998), multiple sclerosis (Sharief, 2002) and a variety of subclasses of acute myeloid leukemia (Salih et al., 2001) or hematological malignancies (Hulmut et al., 2001) have elevated levels of $s 4-1 B B$ or $s 4-1 B B L$.

Serum levels of $\mathrm{s} 4-1 \mathrm{BB}$ and $\mathrm{s} 4-1 \mathrm{BBL}$ were also correlated with disease severity in RA patients (Figure $5)$. The levels of $s 4-1 B B$ and $s 4-1 B B L$ did not strictly correlate with surface expression levels of 4-1BB or $4-1 \mathrm{BBL}$ (data not shown), indicating that the soluble forms of the receptor are not merely produced by shedding of the membrane-bound receptors. This is in line with generation of $s 4-1 B B$ or $s 4-1 B B L$ from distinct, differentially spliced mRNAs or proteolytic cleavage from the cell surface. The inverse relationship between s4-1BB and cell surface 4-1BB suggests that the increased level of $\triangle 4-1 B B$ is associated with a switch from membrane-bound to s4-1BB. They may affect cell-to-cell interactions and responses to ligand, or provoke more specific responses to activation.

Because 4-1BB can be involved in the induction of programmed cell death (Michel and Schwarz, 2000 ), it is tempting to speculate that s4-1BB may regulate apoptosis of activated lymphocytes in a manner similar to other soluble members of the TNF receptor family, such as sFas, which exhibits apoptosis-blocking properties through antagonizing the activity of the membrane-bound receptor (Cheng et al., 1994; Cascino et al., 1996). Indeed, high circulating levels of $\mathrm{s} 4-1 \mathrm{BB}$ have been suggested to suppress immune responses in inflammatory diseases by providing a mechanism to escape immune surveillance, partly through the modulation of apoptosis (Michel et al., 1998; 1999). The high level of release of $s 4-1 \mathrm{BBL}$ in patients may permit the cells to escape local immune surveillance by limiting costimulation of the host lymphocytes (Hulmut et al., 2001), and by reducing apoptosis signals through $4-1 \mathrm{BBL}$ back into the tumor cell (Kashii et al., 1999). Thus, in vivo release from cells, and/or dispersion to distal site, may be responsible for some of the pathophysiological effects of the disease. In addition, the high level of release of $\mathrm{s} 4-1 \mathrm{BB}$ or $\mathrm{s} 4-1 \mathrm{BBL}$ from the cell surface may be mediated by different cleavage mechanism in the different patient groups, and is likely to regulate interactions mediated by $4-1 \mathrm{BB}-4-1 \mathrm{BBL}$ in vivo.

Although s4-1BB and s4-1BBL levels were significantly different in the discrete patient groups, we did find a direct relationship between s4-1BB/s4-1BBL and the disease markers such as RF and ESR (Figure 6). In addition, the elevated $s 4-1 B B$ and s4$1 \mathrm{BBL}$ levels characteristic of RA onset rapidly decreased when the patients respond to the treatment as well as serological parameters (Figure 7). Although additional studies are needed, it suggests that s4-1BB and $\mathrm{s} 4-1 \mathrm{BBL}$ levels may serve as a diagnostic tool in assessing disease activity in RA. The importance of serum $\mathrm{s} 4-1 \mathrm{BB}$ and $\mathrm{s} 4-1 \mathrm{BBL}$ release in this autoimmune disease is further illustrated by the positive correlation with clinical severity. As the clinical severity of RA does not necessarily correlate with other disease parameters like CRP and WBC longitudinal 
studies would be desirable including serial monitoring of s4-1BB and s4-1BBL to assess their effect in modulating the clinical course of RA. The correlations we have observed are clearly relevant to the underlying immune activation, but further studies are required of the interactions between the soluble forms and other immune regulators in the serum. In conclusion, we have detected high levels of s4-1BB and s4-1BBL in patients with clinically active RA. In view of the emerging role of $s 4-1 B B$ or $s 4-1 B B L$ in modulating lymphocytes functions, our results suggest a role in regulating lymphocyte function in $R A$. The effect of s4-1BB and s4-1BBL on cell-cell interactions and in the pathological disorders requires further elucidation.

\section{Acknowledgement}

The authors thank Mr. Cho, Do Sik and members of the Red Cross Ulsan Blood Center for supplying human peripheral blood samples.

This project was supported by SRC Fund to IRC University of Ulsan from the Korean Science and Engineering Foundation (KOSEF), the Korean Ministry of Science and Technology, and the Korean Research Foundation grant (KRF-2001-DP0553), and NIH Grant R01 EY 13325 (BSK).

\section{References}

Alderson MR, Smith CA, Tough TW, Davis-Smith T, Armitage RJ, Falk $B$, Roux $E$, Baker $E$, Sutherland $G R$, Din WS. Molecular and biological characterization of human 4-1BB and its ligand. Eur J Immunol 1994;24:2219-27

American College of Rheumatology Ad Hoc Committee on Clinical Guidelines. Guidelines for monitoring drug therapy in rheumatoid arthritis. Arthritis Rhum 1996;39:723-31

Arnett FC, Edworthy SM, Bloch DA, McShane DJ, Fries JF, Cooper NS, Healey LA, Kaplan SR, Liang MH, Luthra HS: The American Rheumatism Association 1987 Criteria for the classification of rheumatoid arthritis. Arthritis Rheum 1988; 31:315-24

Cascino I, Papoff G, De Maria R, Testi R, Ruberti G. Fas/ APO-1 (CD95) receptor lacking the intracytoplasmic signaling domain protects tumor cells from Fas-mediated apoptosis. J Immunol 1996;156:13-7

Cheng J, Zhou T, Liu C, Shapiro JP, Brauer MJ, Kiefer MC, Barr PJ. Protection from Fas-mediated apoptosis by a soluble form of the sFas molecule. Science 1994;263: 1759-62

DeBenedette MA, Shahinian A, Mak TW, Watts TH Costimulation of CD28 T lymphocytes by 4-1BB ligand. J Immunol 1997;158:551-9

Ebata T, Mogi S, Hata Y, Fujimoto JI, Yagita H, Okumura $\mathrm{K}$, Azuma M. Rapid induction of CD95 ligand and CD4+ T cell-mediated apoptosis by CD137 (4-1BB) costimulation. Eur J Immunol 2001;31:1410-6
Futagawa T, Akiba H, Kodama T, Takeda K, Hosoda Y, Yagita $\mathrm{H}$, Okumura $\mathrm{K}$. Expression and function of $4-1 \mathrm{BB}$ and 4-1BB ligand on murine dendritic cells. Int Immunol 2002;14: 275-86

Garni-Wagner BA, Lee ZH, Kim YJ, Wilde C, Kang CY, Kwon BY. 4-1BB is expressed on CD45RAhiROhi transitional T cell in humans. Cell Immunol 1996;10:91-8

Gramaglia I, Cooper D, Miner KT, Kwon BS, Croft M. Co-stimulation of antigen-specific CD4 $\mathrm{T}$ cells by $4-1 \mathrm{BB}$ ligand. Eur J Immunol 2000;30:392-402

Hulmut R. Salih, Helga M. Schmetzer, Christine Burke, Gary C. Starling, Robert Dunn, Renate Pelka-Fleischer, Volkmar Nuessler, Peter A. Kiener. Soluble CD137 (4-1BB) ligand is released following leukocyte activation and is found in sera of patients with hematological malignancies. J Immunol. 2001;167:4059-66

Inaba H, Komada Y, Li QS, Zhang XL, Tanaka S, Azuma E, Yamamoto $H$, Sakurai M. mRNA expression of variant Fas molecules in acute leukemia cells. Am J Hematol 1999; 62:150-8

Kashii Y, Giorda R, Herberman RB, Whiteside TL, Vujanovic NL. Constitutive expression and role of the TNF family ligands in apoptotic killing of tumor cells by human NK cells. J Immunol 1999;163:5358-66

Kienzle G. von Kempis J. CD137 (ILA/4-1BB), expressed by primary human monocytes, induces monocyte activation and apoptosis of B lymphocytes. Int Immunol 2000;12:73-82.

Kim TE, Park SW, Cho NY, Choi SY, Yong TS, Nahm BH, Lee SS, Noh G. Quantitative Measurement of Serum Allergen-Specific IgE on Protein Chip. Exp Mol Med 2002; 34:152-8

Kwon BS, Weissman SM. cDNA sequence of two inducible T genes. Proc Natl Acad Sci USA 1989;86:1963-7

Langstein J, Michel J, Fritsche J, Kreu1992tz M, Andressen R, Schwarz H. CD137 (ILA/4-1BB), a member of the TNF receptor family regulates monocyte activation via reverse signaling. J Immunol 1998;160:2488-394

Langstein J, Michel J, Schwarz H. CD137 induces proliferation and endomitosis in monocytes. Blood 1999;94: 3161-8

Lienhardt C, Azzurri A, Amedei A, Fielding K, Sillah J, Sow OY, Bah B, Benagiano M, Diallo A, Manetti R, Manneh K, Gustafson P, Bennett S, D'Elios MM, McAdam K, Del Prete $\mathrm{G}$. Active tuberculosis in Africa is associated with reduced Th1 and increased Th2 activity in vivo. Eur J Immunol 2002;32:1605-13

Maldonado A, Mueller YM, Thomas P, Bojczyk P, O'Connors $C$, Katsikis PD. Decreased effector memory CD45RA+ CD62L $-C D 8+T$ cells and increased central memory CD45RACD62L+CD8+ $T$ cells in peripheral blood of rheumatoid arthritis patients. Arthritis Res Ther 2003;5:91-6

Matsuno $\mathrm{H}$, Yudoh K, Watanabe $\mathrm{Y}$, Nakazawa F, Aono $\mathrm{H}$, Kimura T. Stromelysin-1 (MMP-3) in synovial fluid of patients with rheumatoid arthritis has potential to cleave membrane bound Fas ligand. J Rheumatol 2001;28:22-8

May KF Jr, Chen L, Zheng P, Liu Y. Anti-4-1BB monoclonal antibody enhances rejection of large tumor burden by promoting survival but not clonal expansion of tumor-specific CD8+ T cells. Cancer Res 2002;62:3459-65 
Melero I, Johnston JV, Shufford WW, Mittler RS, Chen L. NK1.1 cells express 4-1BB (CDw137) costimulatory molecule and are required for tumor immunity elicited by anti-4-1BB monoclonal antibodies. Cell Immunol 1998;190:167-72

Metkar SS, Naresh KN, Manna PP, Srinivas V, Advani SH, Nadkarni JJ. Circulating levels of TNF alpha and TNF receptor superfamily members in lymphoid neoplasia. Am J Hematol 2000;65:105-10

Michel J, Langstein J, Hofstadter F, Schwarz H. A soluble form of CD137 (ILA/4-1BB), a member of the TNF receptor family, is released by activated lymphocytes and is detectable in sera of patients with rheumatoid arthritis. Eur J Immunol 1998;28:290-5

Michel J, Pauly S, Langstein J, Krammer PH, Schwarz $\mathrm{H}$. CD137-induced apoptosis is independent of CD95. Immunology 1999;98:42-6

Michel J, Schwarz H. Expression of soluble CD137 correlates with activation-induced cell death of lymphocytes. Cytokine 2000;12:742-6

Noel RR, Everly CM, John LF, Herman F, Gerald MP, Eng MT. Autoimmune diseases. Manual of clinical laboratory immunology, American Society for Microbiology 1992;723-85

Nozawa K, Kayagaki N, Tokano Y, Yagita H, Okumura K, Hasimoto H. Soluble Fas (APO-1, CD95) and soluble Fas ligand in rheumatic diseases. Arthritis Rheum 1997;40:1126-9

Pender MP. Genetically determined failure of activationinduced apoptosis in immune cells. J Clin Immunol 1998; $15: 1-6$.

Pollok KE, Kim YJ, Hurtado J, Zhou Z, Kim KK, Kwon BS. 4-1BB $T$ cell antigen binds to mature $B$ cells and macrophages, and costimulates anti-m-primed splenic B cells. Eur $\mathrm{J}$ Immunol 1994;24:367-74
Salih HR, Schmetzer HM, Burke C, Starling GC, Dunn R, Pelka-Fleischer R, Nuessler V, Kiener PA. Soluble CD137 (4-1BB) ligand is released following leukocyte activation and is found in sera of patients with hematological malignancies. J Immunol 2001;167:4059-66

Schneider $P$, Holler $N$, Bodmer JL, Hahne M, Frei $K$, Fontana A, Tschopp J. Conversion of membrane-bound Fas (CD95) ligand to its soluble form is associated with downregulation of the proapoptotic activity and loss its liver activity. J Exp Med 1988;187:1205-13

Schwarz H, Valbracht J, Tuckwell J, Kempis J, Lotz M. ILA, the human $4-1 \mathrm{BB}$ homologue is inducible in lymphoid and other cell lines. Blood 1995;85:1043-52

Schwarz H, Valbracht J, Tuckwell J, Kempis J, Lotz M. ILA, a member of the human nerve growth factor/tumor necrosis factor receptor family, regulates $\mathrm{T}$ lymphocyte proliferation and survival. Blood 1996;87:28-39

Seo JH, Han SW, Yin CS, Koh HK, Kim CH, Kim EH, Leem $\mathrm{KH}$, Lee HS, Park HJ, Kim SA, Choe BK, Lee HJ, Yim SV, Kim CJ, Chung JH. Evaluation of a Apo-1/Fas promoter polymorphism in Korean stroke patients. Exp Mol Med 2002;34:294-8

Setareh M, Schwarz H, Lotz M. A mRNA variant encoding a soluble form of $4-1 \mathrm{BB}$, a member of the murine NGF/TNF receptor family. Gene 1995;27;164:311-5

Sharief MK. Heightened intrathecal release of soluble CD137 in patients with multiple sclerosis. Eur J Neurol 2002;9:49-54

Toshihiro N, Peter EL. Cytokine, activation marker, and chemokine receptor expression by individual CD4+ memory $\mathrm{T}$ cells in rheumatoid arthritis synovium. Arthritis Res 2000;2: 415-23

Zhou Z, Kim Y-S, Kim SH, Pollok KE, Kwon BS. Characterization of human homologous of $4-1 \mathrm{BB}$ and its ligand. Immunol Lett 1995;45:67-73 